\title{
Brokers of Change
}

Atlantic Commerce and Cultures in Precolonial Western Africa 


\title{
Dutch Trade with Senegambia, Guinea, and Cape Verde, c.1590-1674
}

\author{
FLLIPA RIBEIRO DA SILVA*
}

TrE D TCH TRADE in the Atlantic is, traditionally $y_{2}$ associated with the monopoly of the Durch West India Company (West-Indische Compagnie [WIC]) established in 1621. However, private entrepreneurship was vital for the functioning of the Dutch Atlantic economy both before and after 1621. The inter- and untra-continental trade demanded high investments in insurance, freight, purchase of cargos, and payment of seamen and commercial agents. The ariculation of the coastal and long-distance circuits required high commercial expertise and wide trading networks covering several geographical areas. The Ewopean entrepreneurs and businessmen in the Dutch Republic as well as their agents overseas were on the genesis and at the basis of this complex șstem of interactions.

Sirice the 1590s, the Dutch Republic was home to a wide mercantile commurrity including not only Dutchmen, but also foreigners, such as Flemish ard German merchants. However, for convenience, we will refer to them as 'Dutich' businessmen. The Dutch mercantile community also comprised an artive group of Portuguese Sephardic merchants. The group had taken refuge in the Republic after the establishment of the Inquisition in Portugal (1536) and the blockade of Antwerp (1584-85) by the Dutch insurgents as a consequence of the city's economic decline.

For the past twenty years, several scholars have studied these mercantile sroups. Nevertheless, little attention has been paid to the economic activities

- waind Ithe to acknowledge the Portuguese Foundation for Science and Technology (Fundaçăo a Cxinta e Tecnologia) for sponsoring the research for this chapter, as part of a Ph.D. dissertation The Durch and the Portuguese in West Africa: Empire Building and Atlantic System, 1580if - Lexdert Liniversity, June 2009. Recently published by Brill with the title Dutch and Portuguese

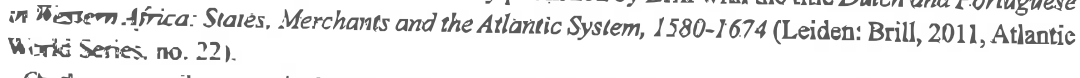

On the mercantile groups in the Republic, see Cátia Antunes, Globalisation in the Early Modern Period: The Economac Relationship between Amsterdam and Lisbon, 1640-1705 (Amsterdarn: Aksant, 2004);

Prxaedings of the British Academy, 178, 125-147. (C) The British Academy 2012. 
of these private investors in the early trade with the western coast of Africa. This chapter sheds some light on this subject by analysing the interests of the private businessmen from the Republic in Senegambia, Guinea Bissau, and Cape Verde, and their conflicts and forms of cooperation with the WIC. It also looks into the conflicts opposing these entities and their impact on commerce. Transactions involving Dutch, Sephardim, Portuguese, and Euro-African merchants are explored as well.

First, we pay attention to the entrepreneurs based in the Republic financing the insurance of ships and cargos for Senegambia, Guinea Bissau, and Cape Verde. To understand the origin of the capital covering the risks of this trade, we also briefly look at their other economic activities. Secondly, we focus on the businessmen operating in the long-distance circuits connecting the regions mentioned above with Europe and the Americas. Here, we aim to identify the most important European merchants investing in this trade and to enumerate their main business interests. To achieve these goals we check areas of investment and commodities traded. In the final section of the chapter, we look at the commercial agents of the European merchants controlling the trade in the Dutch posts in Senegambia, Guinea Bissau, and Cape Verde.

C. Lesger, Handel in Amsterdam Ten Tijde Van de Opstand: Kooplieden, Commerciële Expansie en Verandering in de Ruimtelijke Economie van de Nederlanden ca. 1550-ca. 1630 (Hilversum: Verloren, 2001); O. Gelderbloom, Zuid-Nederlandse Kooplieden en de Opkomst van de Amslerdamse Stapelmarkt (1578-1600) (Hilversum: Verloren, 2000); C. Lesger and L. Noordegraaf (eds), Entrepreneurs and Entrepreneurship in Early Modern Times: Merchants and Industrialists Within the Orbit of the Dutch Staple Markel (Den Haag: Stichting Hollandse Historische Reeks, 1995); P. W. Klein, De Trippen in de 17e Eeuw: Een Studie Over het Ondernemersgedrag op de Hollandse Stapelmarkt (Assen: Van Gorcum, 1965). On the Portuguese Sephardim in the Republic, Wester Europe, and the Atlantic in general, see Daviken Studnicki-Gizbert, A Nation upon the Ocean Sea Portugal's Atlantic Diaspora and the Crisis of the Spanish Empire, 1492-1640 (Oxford: Oxford University Press, 2007); idem, 'La "Nation" Portugaise: Réseaux Marchands dans l'Espace Atlantique à la Époque Moderne', Annales HSS 58/3 (2003): 627-48; Cátia Antunes, Globalisation in the Early Modern Period; Jonathan I. Israel, Diasporas within A Diaspora: Jews, Crypto-Jews, and the World Maritime Empires (1540-1740) (Bosto Mr Me of Mercanilism, 15s0 1750 (London: Clarendon Press, 1998), Paolo Bernardini and Norman Fierin (eds), The Jews and the Expansion of Europe to the West. 1450-1800 (New York: Berghahn, 2001); Yosef Kaplan, An Alternative to Modernity: The Sephardi Diaspora in Western Europe (Boston and Leiden: Brill, 2000); O. Vlessing, 'The Portuguese Jewish Merchant Community in 17th-Century Amsterdam', in C. Lesger and L. Noordegraaf (eds), Entrepreneurs and Entrepreneurship in Early Modern Times, 223-4; Daniel Swetschinski and L. Schönduve, De Familie Lopes Suasso: Financiers van Williem III/The Lopes Suasso Family, Bankers to Willem III (Zwolle: Waanders, 1988); Danie M. Swetschinski, Reluctant Cosmopolitans: The Portuguese Jews of 17 th-Century Amsterdam (London: The Littman Library of Jewish Civilisation, 2000); idem, 'Kinship and Commerce: The Foundation of Portuguese Jewish life in 17th-century Holland', Studia Rosenthaliana 15/1 (1981): 52-74; idem, 'The Portuguese Jewish Merchants of Seventcenth-Century Amsterdam: A Social Profile' (unpublished Ph.D. dissertation, Brandeis University, 1980)
The study of the entrepreneurs, businessmen, and agents operating from the Republic is based on a set of 341 notarial contracts collected from the S.uncipal Archive of Amsterdam (Gemeente Archief van Amsterdam, Notariale that [A Not Arch]). This set comprises all notarial contracts regarding the buress activities of the merchants of this Dutch port with the westem ast trica for the period 1580 to 1674 . This selection includes various or notarial contracts such as insurance and commercial partnerships as a 18 sommercial agreements, labour contracts, and powers of attomey. In E-y =-intical terms, this set includes all contracts for Senegambia, Guinea Els.t. Cape Verde, Sierra Leone, Grain, Gold, Ivory and Slave Coasts, São 70 and Principe, Loango, Kongo, and Angola. In this chapter we analyse : : the contracts for the first three areas mentioned. ${ }^{2}$

Lu snasis of the entrepreneurs, businessmen, and agents is based on zatuctes of the economic activities of certain individuals. The selection of thes: merchants has been made with regard to the number and quality of -.miry sources available.

The chapter covers three different periods: (1) c.1590-1623; (2) 1624-38; thit $16: 4-74$. These chronological boundaries are essential because the uncl tramework regulating commercial activities in the so-called Dutch than in general, and the westem coast of Africa in particular, changed $x=-$ Whe. While the first period corresponded to an era of free trade, after the as-biment of the WIC (1621-24), private merchants were prohibited from ating westem coast of Africa and other areas in the Atlantic, and a fere forces to remove their assets and personnel from the commercial posts win a period of two years (1623). ${ }^{3}$ These commercial restrictions were in ... a-1. 1638 for Brazil and 1648 for North America and the western coast of An. Fow ever. from the early 1640s onwards, the signs of economic decline -a. emerge and the WIC's incapacity to conduct trade and guarantee the gouds in the intercontinental routes led to a gradual opening up : E somercial monopolies to private businessmen. ${ }^{4}$ Therefore, after the

Zuf Sef contrats is part of a bigger sample comprising $c .17,000$ notarial contracts covering the fritest Baltic. and the Mediterranean between 1580 and 1750. Work in progress by Cátia trans and Filipa Ribeiro da Silva.

4 Legislation. Jurisprudence, and Law in the Dutch West Indian Colonies: The Order ef If20'. Pro Memorie 5/2 (2003): 320-1; H. den Heijer, 'Directores, Stadhouderes e

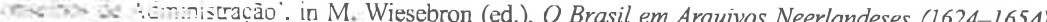

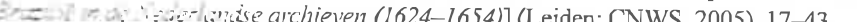

The Gentiemen Nineteen had been discussing the possibility of opening up the monopoly ithe sive :-ze in Luanda to private merchants from the Republic, since the WIC employees had the thispable of stopping the decline of the trade, and the various chambers of the company = efe unathe to sed regular cargoes of exchange commodities without the cooperation of private 
1640 s, and especially in the 1650s and 1660s, there was a revival of private investment from the Republic into the western coast of Africa.

Thus, in the first period we focus on the economic activities of the private entrepreneurs, businessmen, and agents operating in Senegambia, Guinea Bissau and Cape Verde, whereas in the second period we examine the commercial organization of the WIC and its activities. In this period, we also look at the activities of the interlopers whenever the primary sources make this possible. ${ }^{5}$ In the latter period, we analyse the activities of the WIC and the private insurers, merchants, and agents authorized to operate in the areas controlled by the WIC and within certain branches of the monopoly.

\section{Entrepreneurs}

The regions of Senegambia, Guinea Bissau, and Cape Verde became part of the financial and commercial activities of the entrepreneurs and businessmen of the Dutch Republic in the late sixteenth century. Since the 1590s, 'Dutch' entrepreneurs had been backing the risks of the ships freighted in the Republic to operate in two main intercontinental circuits connecting the Seven Provinces to Senegambia and the Cape Verde Islands, ${ }^{6}$ as well as in the port-to-port navigation in these two regions. ${ }^{7}$ However, only a few European entrepreneurs had enough capital to be insurers.

merchants. This discussion resulted in a regulation that granted the privale merchants from the Republic permission to send vessels to Luanda to buy slaves and to transport them preferably to New Holland (Brazl) and the West Indiss. This regulation was only rinted in pamphlet form and to New by the States General in 1648 . However, given the multiple references to independent colonists and independent merchants in Luanda from the mid-1640s, it is likely that this regulation was put into practice before it had been approved by the States General. G[emeente]a[rchief van] A[msterdam], 54: Reglement [...] over the openstellen van de handel op S. Paulo de Loanda. The Hague, 1648; K. Ratelband, Os Holandeses no Brasil e na Costa Africana. Angola, Kongo e São Tomé (1600-1650) (Lisboa: Vega, 2003), 310-15.

Between 1624 and 1648 the number of notarial contracts concerning the commercial activities of private merchants is lower. Nevertheless, there are mulliple examples of notarial acts by the WIC and private businesents as well as betwe the

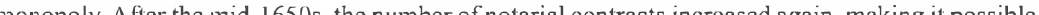
follow in detail the economic activities of the several mercantile groups of the Dutch Republic investing in the westerm coast of Africa.

Whereas the first route linked the Republic to Senegambia and the Guinea Bissau region, the second route connected the Dutch ports to the Cape Verde islands: Filipa Ribeiro da Silva, 'Dutch Vessels in African Waters: Coastal Routes and Intra-Continental Trade (c.1590-1674)', Tijdschrift voor Zeegeschiedenis 1 (2010), 19-38. For examples, see GAA Not[arial] Arch[ive] 124/125-126: 16 March 1611. Not Arch 160/28 29v: 4 October 1619.

Until the early seventeenth century, the ships freighted in Dutch ports to conduct trade between the Republic and the western coast of Africa were often the same that carried out the coastal trade in Africa
Among those who could afford to be insurers in the Dutch Republic were 4. eral important merchants of Amsterdam, namely: Jan Jansz Smits, Claes Andresz. Aloert Schuijt, Barent Sweets, and Jan de Clerck. Less prominent in the insurance business with Senegambia, Guinea Bissau and Cape Verde, bu sull ietr? scrive were: Pelgrom van Dronckelaer, Anthoni van Diemen, Hans va Solt. Hans van Geel, Hendrick Voet, Willem Pauw, Van den Bogaert, Wijoran 27ot actwines developed by these businessmen with regard to the regions gus menmoned. we will look into the activities of Jan Jansz Smits and his 3astates

I.t Jens I Smits, businessman in Amsterdam, started his insurance activities It 1012 with sips destined to the western coast of Africa and other areas in the -1 nuc namely Brazil, the West Indies, Portugal, and Spain. In general, Jan Jansz imits worked in partnership with Claes Adriaesz, Barent Sweets, zox Aller. Schuijt." Claes Andriesz and Barent Sweets were two powerful thentuns fom Amsterdam, especially active in the trade between Portugal, the R.phic. and the Baltic. However, they also operated as insurers of vessels seling from the Republic and Portugal to Cape Verde and Guinea, and the Swathro +ilantic waters, to both Angola and Brazil. ${ }^{10}$ As for Albert Schuijt, ta - wa a eter in Amsterdam, specializing in the insurance business, mainly -7th the sesern coast of Africa and Brazil. Schuijt started his insurance c.w.tus in 1614 and remained active until 1623. In the early years of his vokes. be mainly insured ships operating the routes connecting Europe, them coast of Africa, and the Americas. However, later Schuijt almost evituely steguarded vessels involved in the Brazilian trade. His highest

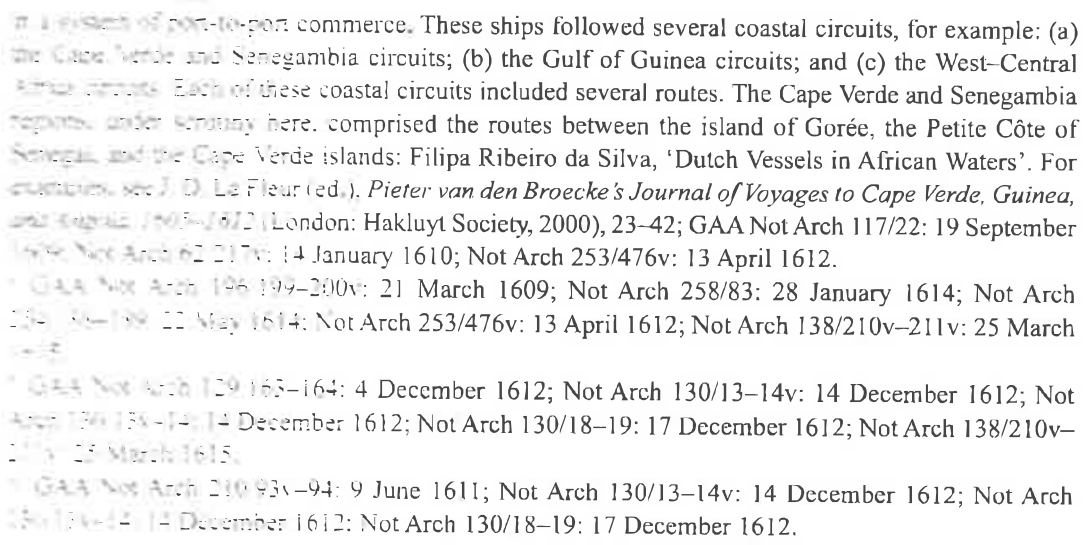


volume of insurance business was in the routes linking Brazil to Portugal, namely Lisbon, Viana do Castelo, and Porto."

Like Schuijt, Jan Jansz Smit expanded his insurance business to the com mercial routes linking Brazil and Europe. ${ }^{2}$ However, as with the western coast of Africa, in the insurance activities concerning Brazil Jansz Smit operated mainly in partnership with other merchants to lower the risks. Among his partners one should be mentioned in particular, Hans van Soldt de Jonge, who also participated in the insurance business for the western coast of Africa, as well as men such as Bartholomeus and Abraham Bisschop, and Wijbrant Warwijck. ${ }^{13}$

Many of the ships, cargoes, and return goods insured by these merchants were the property of Portuguese Sephardic merchants living either in Portugal or in the Republic. For instance, in 1612, Jan Jansz Smit, in association with Claes Adriaesz, Jan de Clerk, and Jasper Grevenraet, insured several goods for Diogo da Silva, such as hides, elephant tusks, gold, and other merchandise loaded on board the St Jacob, skippered by Harpert Martens from Rotterdam, for a trip from Cape Verde to the Republic. ${ }^{14}$

The Dutch entrepreneurs insured not only the ships and cargoes of the Dutch merchants and the Portuguese Sephardic Jews established in Amsterdam, but also most of the vessels sailing the long-distance routes of the Portuguese Allantic. The Portuguese historian Costa has emphasized that the majority of the businessmen operating in the Portuguese Atlantic had their ships and commodities insured in Amsterdam. ${ }^{15}$ This option could have been a solution for a possible lack of capital in Portugal. However, it is more likely that it was a well-thought-out strategy to spread risk and avoid major losses within the same mercantile group. In fact, the members of the Portuguese Jewish Nation of Amsterdam, some of them renowned as very wealthy businessmen, used a similar commercial strategy.

Usually, the Portuguese Sephardim in Amsterdam acted as contacts for the mercantile groups in Portugal to obtain their insurance in the Republic Often, they were the commercial partners of businessmen operating from

"GAA Not Arch 258/83: 28 January 1614; Not Arch 254/188-189: 22 May 1614; Not Arch 317/339: 29 May 1615; Not Arch 378A/339: 29 May 1615; Not Arch 379/606: 17 November 1616; Not Arch 379/614: 25 November 1616; Not Arch 379/618: 2 December 1616; Not Arch 379/633-633v 9 December 1616; Not Arch 379/633: 9 December 1616; Not Arch 385/202: 20 August 1622

12 GAA Not Arch 376/229: 26 April 1613.

${ }^{13}$ GAA Not Arch 377/74: 1 March 1614; Not Arch 377A/74: I March 1614

${ }_{14}$ GAA Not Arch 129/163-164: 4 December 1612; Not Arch 130/13-14v: 14 December 1612; No Arch 130/13v-14: 14 December 1612; Not Arch 130/18-19: 17 Deccmber 1612. Livros Horizonte, 2002), 79 .
Portgal and the Portuguese Empire. For instance, João Soeiro, contratador f the Cage Verde and the Guinea royal monopoly between 1608 and 1614 , te the of 'his factors' connections with the Sephardic Jews to freight and - sure cosels in Annsterdam. ${ }^{16}$ In addition, by conducting direct trade between - Re-utlic, the Petite Côte of Senegal (also included in the aforementioned $-\infty)$ ind the Republic, the ships could avoid calling at the ports of (trenande iSantiago, Cape Verde) and Lisbon, where several taxes had to to the roval treasury. Soeiro's main contacts in Amsterdam were Famandes. Gaspar Nunes, Duarte Fernandes, Pedro Rodrigues da ega 2 wher. For example, on 5 August 1611, Gaspar Femandes transported toos for Duste Fernandes, on board Het Vliegende Hert sailing from fortardam io Porudal (present-day Saly-Portudal, Petite Cote, Senegal), fider th command of skipper Alewijn Jansen from Rotterdam. The value the mothandise transported to Portudal and the insurance premium was . at the insurnce premium for the return voyages amounted to 2,552 Flemish pords Duare Femandes was probably a holder of a commercial licence 4 Jo 5oziro to conduct trade within the area of the monopoly. ${ }^{17}$

Tho wher important associates of João Soeiro were Diogo da Silva and yo Dras Cuerido. both merchants in Amsterdam and connected to Soeiro a the common agents in Senegambia and the Guinea Bissau region: Simão onces Plne! and Estêvão Rodrigues, factors of the contratador on the were $F$ omple. on 19 January 1611, Diogo da Silva and Diogo Dias henvio sant some goods in the ship Santiago, skippered by Herbert Marselssen vecterdarn. sailing from Rotterdam to Portudal and Joal (present-day at watowh. Perite Cote, Senegal). The value of the cargo amounted to - Frmish pounds. Simão Rodrigues Pinel and Estevão Rodrigues were toxtestive the rade on the coast. Hides, ivory, and other African goods te torered for European cargo. They planned to stay six months in ... E. A ¿riaen Andriesz, Wijbrant Warwijck, and Anthoni van Diemen the cargo. The ship sailed from Portugal to several places on to coss Guinea and returned to the Republic. Claes Andriesz, Jaspar Garen: Sweerts, and Jan Jansz Smits, all merchants in Amsterdam, sured the rewm cargo.!"

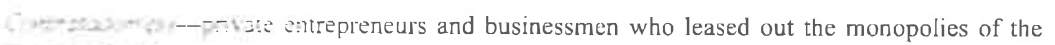
$\cos c-\infty \pi n$

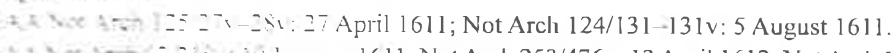

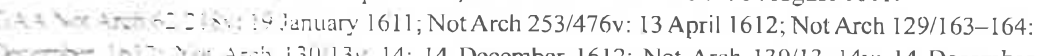
16: Arci :30) 13v-14: 14 December 1612; Not Arch 130/13-14v: 14 December : $>x+26: 19-14: 1-$ December 1612. 
After 1640 , the businessmen operating in Portugal continued to freight

Drang this early period, the majority of the notarial contracts in our sample and insure their ships and cargoes in Amsterdam, especially those used in soostring the trade with the western coast of Africa, in general, and the comthe European trade..$^{19}$ The data available for the trade with the western coast terts with ine Senegambia, Guinea Bissau and Cape Verde, in particular, of Africa does not give detailed information regarding the insurance in this atentes beneen 'Dutch' private traders. As a representative case study of chronology.

Dusch commercial activities in the regions just mentioned, we have selected

During the strict monopoly of the WIC over the Atlantic (1621-37) infor- the testress of Gerrit van Schoonhoven, merchant of Middleburg.

mation on the insurance activities of the aforementioned entrepreneurs is very scarce. The limited number and the nature of the primary sources concerning athes thil the establishment of the Dutch West India Company (1621-24). the WIC do not allow an identification of the insurers of the company. Hs Nevertheless, after the WIC started to open up its monopoly to private astract be traced between 1604 and 1621.

investment, the insurance activities of the entrepreneurs of the Republic reappear in the notarial contracts.

\section{Businessmen} vente an individual merchant around the year $1604 .{ }^{21}$ However, by 1613 vat swothon declared that he had been doing business on the coast of Corre wish with Cornelis Munnicx, also a merchant from Middleburg

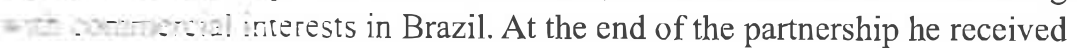

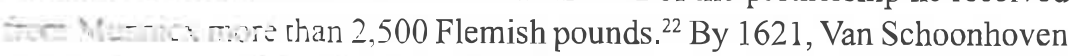
Whereas the entrepreneurs held the capital required to cover the risks, the tocterd ss one of the directors of the Compagnie van Guinea, together with businessmen had the commercial knowledge and connections to shipping and tar trade. Between $c .1590$ and 1623, there were two different groups of merchants in the Republic with economic interests in the western coast of Africa: the in $1 \mathrm{C}$ 'Dutch' merchants and the Portuguese Sephardic Jews established in Amsterdam. and other Dutch cities.

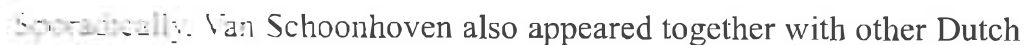
imsterciam as insurers of vessels and cargoes of Portuguese

The 'Dutch' businessmen started their economic activities in the Atlantic in the late 1580s, often organized in small private commercial companies. ${ }^{2}$ an: For

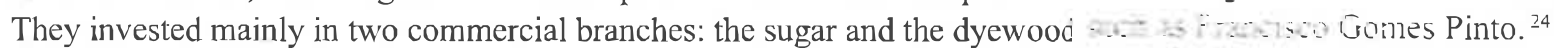

trade from Brazil; and the gold, ivory, and leather trade from the westerr the the coast of Africa. The slave trade was a minor commercial activity for most of mestents in the Republic investing in Western Africa. captaincies.

${ }^{19}$ Cátia Antunes, Globalisation in the Early Modern Period, 91-122, 123-40.

${ }^{20}$ Among those companies were, for example, the Compagnie van Guinea, represented by Gerrit vat Schoonhoven, Jan Gerritsen Meerman, and Elias Trip; the company of Nicolaes Balestel; the compan! of Philips Thijssen; the company of Adriaen, Marten, and Guilliaume Papenbroeck; and the compan of Hans Willemsen Elbinck. In addition, there were many other Dutch and Flemish individual privatt merchants involved in the trade with the westerm coast of Africa, such as Frans Jacobsen Hinloopen Samuel Bloemert, Lucas van de Venne, Frans Steenhuijsen, Hans Franx, Hans Rombouts, and Piete Sijmonsz Snellinck all merchants in Amsterdan. Abraham de Velaer Michiel Pauw, Melchior van d

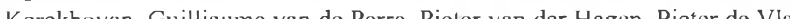
Kerckhoven, Guilli all me van de Perre, Pieter van der Hagen, Pietcr de Vlamingh, Jan Verlon, Stever Groulaert, Jan du Bois, Philip van der Beeck, and Willem Brasser were also among the merchan investing in the trade with the western coast of Africa. GAA Not Arch. Dax Petandes. Diogo da Silva, the Belmonte family, Diogo Vaz de Sousa, and Eces So Rotrigues Penso. ${ }^{25}$ Based on the notarial contracts, we have s. c.t. conomic activities of Gaspar Sanches and his associates as a

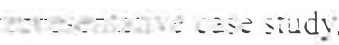

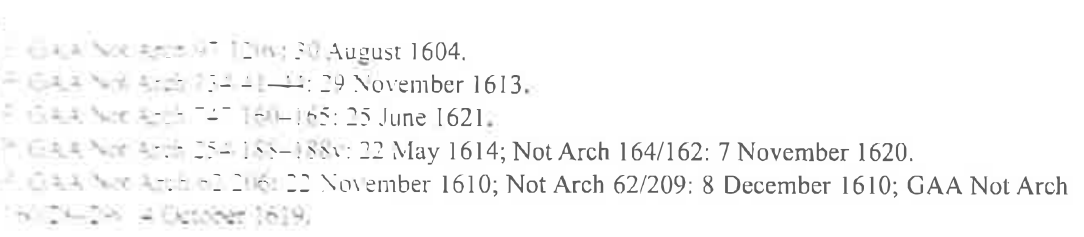


Gaspar Sanches, a Portuguese merchant resident in Rotterdam, and Gaspar Nunes, a merchant in Amsterdam, were probably the most dynamic Sephardic businessmen in Senegambia, Guinea Bissau, and Cape Verde during the first two decades of the seventeenth century. Sanches and Nunes together organized several commercial trips to these areas. Their main areas of business were the ports of Portudal, Joal, and Rufisque (present-day in the Petite Côte, Senegal), and the islands of Cape Verde. For example, on 19 September 1609, the two Portuguese merchants together freighted the St Jacob, of 80 last, ${ }^{26}$ to sail from Rotterdam to Portudal, under the command of skipper Govert Jansen from Rotterdam. Rotterdam was the port of departure and the final destination. The cargo cost was 7,000 guilders. In 1610, Gaspar Sanches and Gaspar Nunes freighted the same vessel and skipper to sail to the same destination. This may be a sign of specialization. However, the contracts do not give further details on the price of the cargoes. ${ }^{27}$

Gaspar Sanches and Gaspar Nunes also participated in the trade in hides with Cape Verde. On 14 January 1611, Paulus Claesz declared that a cargo of hides from the Cape Verde producers had arrived in Rotterdam on board the vessel of Govert Jansen with Gaspar Fernandes, probably the supercargo put on board the vessel to conduct the business in Cape Verde. Paul Claesz, in on board the vessel to conduct the business in Cape On 31 January of the following year, the same duo of traders hired the skipper Govert Jansen to travel once again to Cape Verde. ${ }^{28}$

Sanches and Nunes were also associates of other Portuguese Sephardic merchants of Amsterdam doing business in the same areas of Western Africa. Gaspar Sanches had occasional partnerships in his commercial enterprises to Portudal and Cape Verde with Pedro Rodrigues da Veiga and Duarte Fernandes. For instance, on 24 December 1610, Gaspar Sanches and Pedro Rodrigues da Veiga freighted the ship Het Vliegende Hert, skippered by Heyns Claessen, to sail from Amsterdam to Portudal. ${ }^{29}$

Gaspar Nunes joined in business with João Lopes da Costa and Antonio Nobre, as well as with Pierre Thonen and Pierre Bacquelarot, merchants in

${ }^{26}$ Last was an old measure of weight used in the Dutch Republic. One last equaled 2,000 kilograms or two tonnes.

27 . 117/22-23: Arch 19 Septerner 1609. Nor Arch 62/195v: 30 September 1610

117/22-23: 19 September 1609) Nor Arch 62/: Not Arch 62/219: 19 January 1611; Not Arch 62/421: 2 January 1612; Not Arch 62/589: 31 January 1612.

29 GAA Not Arch 62/210v: 24 Deccmber 1610; Not Arch 125/27v-28v: 27 April 161l; Not Arch 124/131-131v: 5 August 1611.
Anstonem. The trade with Guinea conducted by Gaspar Nunes in partnership with a covementioned merchants connected the Republic to the Petite Côte i Sercsal and the port of Dieppe (Normandy, France), where Luis Fernandes, then-law of Gaspar Nunes, was the main contact person. On 20 September iviz. Crepar Nunes had a total debt of 2,622 guilders and 33 stuivers in three culls aschange issued by Pierre Thonen and Pierre Bacquelarot. ${ }^{31}$ These comtretcti! parnerships tell us much about the wide network of the Sephardic mercisalts inroughout Europe and the European Atlantic possessions.

After the establishment of the WIC (1621-24), the private traders in twe veriands officially had to suspend their activities in Western Africa. How ever. min: continued to freight ships to these areas. Therefore, private zosmesmen kept devising strategies to purchase forbidden commodities ant tode avation by avoiding paying the company for commercial licences. Ther presence in the areas under the jurisdiction of the WIC increased even - ater the company decided to open up the commercial monopolies regarding tat o B-zill and the New Netherland (present-day New York), in 1638 and

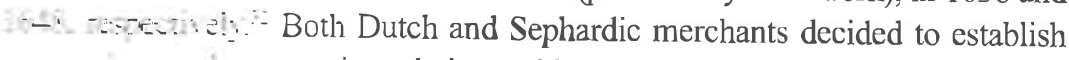
and couperative relations with the WIC. For example, in the 1660s, jerac va 6 icke: ovr. Pieter van Uffelen, Adriaan Brugman, and Joost Glimmer, mestians in Amsierdam, appear to have been associated with the WIC, more whe Chamber of 'City and Surrounding Land', that is, Groningen, is tre Certhe R. ar wade. In fact, the directors of the WIC Chamber of Groningen armet themission to equip ships and supply cargoes to the Gambia River,

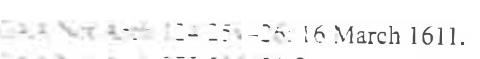

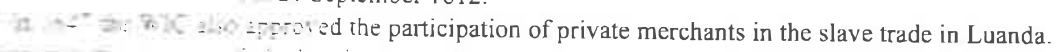

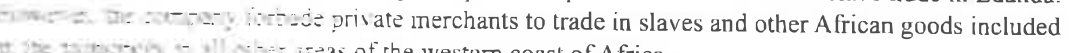

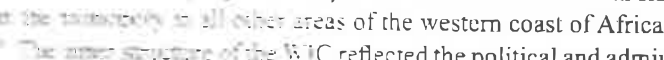

7x nessevertere of the WIC reflected the political and administrative frameworks of the Republic. and Amsterdam, Zealand, Northern Quarter, Maas, and the Chamber of

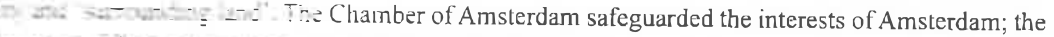

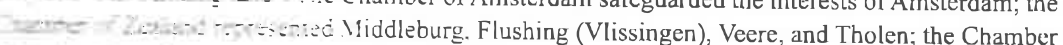

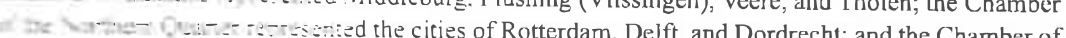

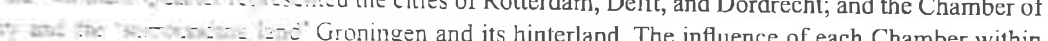

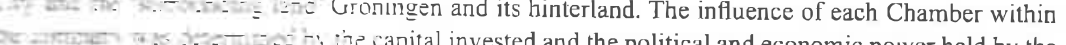

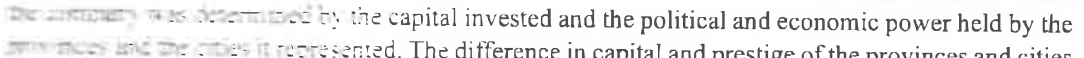

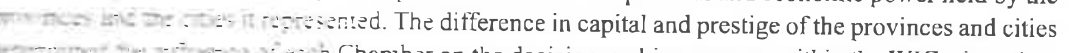

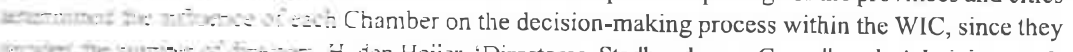

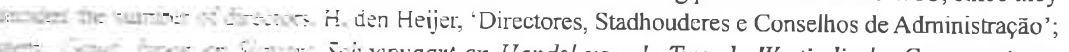

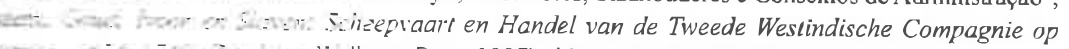

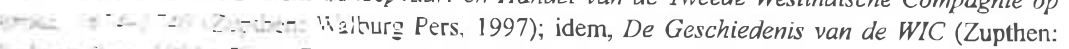

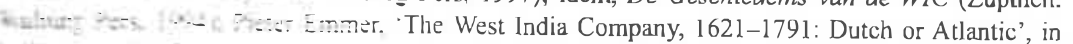

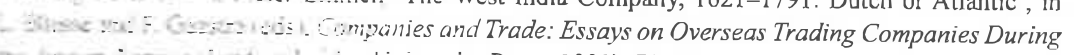

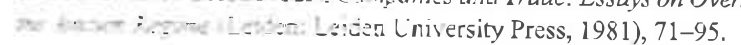


after 12 August 1657. In order to gather all the required ships they gave power of attorney to Pieter van Wickevoort to freight the ship De Vrede, skippered by Frans Jansz Backer from Burgerdam, and load the required cargo in Zealand on 3 March 1660. The following month, these merchants freighted the ship De Gouden Burgh, under the command of skipper Jacob Cley from Middleburgh, to sail with goods and provisions for eight to nine months from Amsterdam to the Gambia River and back to Amsterdam or elsewhere in the Republic. The freight would amount to 1,400 guilders per month. ${ }^{34}$ However, Johan van Wickevoort and Joost Glimmer claimed that persons of the Chamber of Amsterdam considered them to be lacking in experience, and had treated them as enemies and inexperienced merchants. This accusation was probably true for Joost Glimmer, but not for the other businessmen. Pieter van Uffelen, a member of the Van Uffelen family, started his economic activities in Western Africa, more precisely Cape Verde, Gambia, and Sierra Leone, as early as 1614 in partnership with Michiel Block. ${ }^{35}$ Johan van Wickevoort had business connections with the Spanish-American colonies, the West Indies, and the Caribbean Islands, especially Jamaica. His main partner in this business was Henrico Matias, an influential German merchant based in Amsterdam with wide commercial interests in the western coast of Africa, the Spanish-American colonies, Brazil, Spain, and Portugal. These disputes may also have been due to the commercial jurisdictions of the chambers over the different regions of the westem coast of Africa.

\section{Commercial agents}

To conduct trade in the western coast of Africa, the 'Dutch' and the Sephardic businessmen needed either to live at the posts, take part in the commercial journeys, or place their economic agents at key points in the commercial circuits. These men needed to establish cooperative relations with other economic agents already settled on the Westem African coast, namely Portuguese, other Europeans, Euro-Africans, and Africans

During the early period of Dutch presence in the western coast of Africa, the merchants of the Republic did not have any formal commercial organization. Therefore, the different private companies had businessmen and

39 GAA Not Arch 1132/21-22: 30 January 1660; Not Arch 1132/229: 3 March 1660; Not Arch 1540/138: 7 April 1660

35 The Van Uffel Bhe Var U 21 October 1659; Not Arch 97/76: 5 August 1604; Not Arch 102/212: 9 March 1606; Not Arch 138/7: 4 September 1614-09-04.
- covinints iravelling on board the ships or placed on shore and on board Areng rading posts-leggers. These commercial personnel were organized werchically the leader being a chief merchant or chief factor, with several -tor mechants, sub-factors, accountants, and bookkeepers working under alabersio isee Figure 5.1). ${ }^{36}$

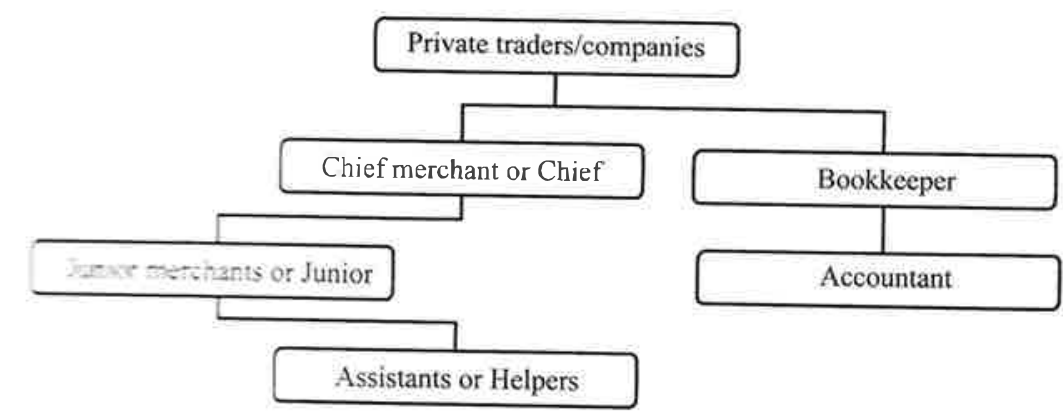

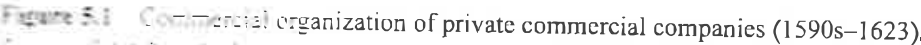

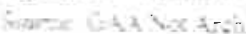

Fae superargoes sent to Senegambia, Guinea Bissau, and Cape Verde x seart the ships to conduct trade on the coast could either be one of the atenten investing in the commercial venture or commercial staff hired Ane the inghting the ship and investing in the trip. Both the Dutch Int the Por $=-1+2$ Sephardic merchants did this. For example, on 24 December * Cover Sances and Pedro Rodrigues da Veiga freighted the ship Hel

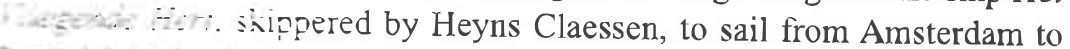
Porsie. ?airo iz leiga and his brother Gaspar Fernandes travelled on board the 5 the merchandise on the coast. ${ }^{37}$

- co wes. the main investors in these commercial joumeys stayed if tortad hired other supercargoes to go on board the vessels and trade The werevitives on the coast. Both the Dutch and the Portuguese Sephardim artes on the business on in Senegambia, Guinea Bissau, und Care 1.tes. For instance, on 19 September 1609, Gaspar Nunes and Cever Santys hired Luis Fernandes and Gaspar Fermandes, respectively. These the St Jacob, with all costs and voyage Ante the it the Pente Coie of Senegal, they conducted trade at Portudal, Joal, whe R.t.ther good example was the team of supercargoes of Diogo

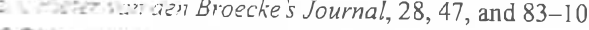

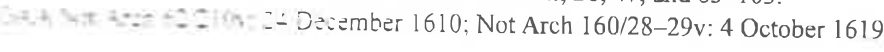


da Silva; Simão Rodrigues Pinel and Estevão Rodrigues were among them. They had to travel several times on board vessels freighted by Diogo da Silva and his partners for these commercial ventures to conduct trade on the Petite Côte of Senegal on their behalf. ${ }^{38}$

The different commercial firms operating in the Senegambian, Guinean and Cape Verdean trade also contracted factors to be their permanent agents on the coast. For instance, Gerrit van Schoonhoven, partner in the Compagnie van Guinea, together with Elias Trips and Jan Gerritsen Meermaan, hired several men. In 1613, Van Schoonhoven and his partner Cornelis Munnicx already had factors in Guinea. Later, Van Schoonhoven hired other men, namely Rombout Pils, Hendrick van Domselaer, Carel Tresel, and Gerrit Laurens Rijser. The former two were in his service in Guinea in 1617. Carel Tresel was hired a second time in 1618 to be the senior factor-oudere commis - to conduct trade in the same area for a period of two years, receiving a monthly wage of thirty-six guilders. The latter, Gerrit Laurens Rijser, was hired in the same year to travel on board the ship Jupiter, also trading in Guinea for a similar period of time, with a monthly salary of thirty guilders. ${ }^{39}$ Van Schoonhoven's factors conducted trade mainly in gold and elephant tusks; such products were bartered for oil, alcoholic beverages, and beans. ${ }^{40}$

The Sephardic merchants also signed labour contracts with several traders to be their factors in Senegambia, Guinea Bissau and Cape Verde. For instance, Diogo da Silva and partners kept factors permanently on the Petite Côte of Senegal. Simão Rodrigues de Noe and Diogo Vaz (de Sousa) were two of those men. Another good example is Diogo Dias Querido, also a Portuguese Sephardic Jew in Amsterdam. In 1612, he freighted the ship Jonas under the command of skipper Douwe Annes of Enkhuizen, for a trip from Amsterdam to Senegambia stopping at Cape Verde (on the continent), Portudal, Joal, and Rufisque. The skipper and crew were supposed to receive an open letter from his factor on the coast, Jacob Peregrino or Pelegrino; stating that he had fulfilled his obligations. ${ }^{41}$

The businessmen operating in the Petite Côte of Senegal as factors of the Sephardic businessmen in Amsterdam, as well as those on board their vessels,

${ }^{38}$ GAA Not Arch 115/22-23: 19 September 1609; Nol Arch 117/22: 19 September 1609; Not Arch 117/22-23: 19 September 1609; Not Arch 62/206: 22 November 1610; Not Arch 62/209: 8 December 1610; Not Arch 62/218v: 19 January 1611

39 GAA Not Arch 645/29-30v: 28 July 1617; Not Arch 151/207v: 4 April 1618; Not Arch 151/208: 4 April 1618.

10 GAA Not Arch 645/29-30v: 28 July 1617.

${ }^{41}$ GAA Not Arch 62/218v: 19 January 1611; Not Arch 128/182-183: 19 September 1612; Not Arch 645/887: 22 January 1620
1. ¿re classified by the Portuguese Crown as lançados. In fact, some of these Ten even had institutional ties with the contratadores of the royal monopolies 0 : the economic areas of Senegambia and Guinea Bissau under the jurisdic tion of the Portuguese Crown. For example, Luis Fernandes, supercargo Of Gaspar Nunes, and Simão Rodrigues Pinel and Estêvão Rodrigues ( Penso), supercargoes of Diogo da Silva, as well as Jacob Peregrino, factor of Diof Diogo Dias Querido, were also factors of the Portuguese contratador of the monopoly of Cape Verde and Guinea between 1608 and 1614, João Soeiro. Pedro Rodrigues da Veiga, partner and supercargo of Gaspar Sanches, was aiso among Soeiro's factors. ${ }^{42}$ Jacob Peregrino, factor of Diogo Dias Querido, had business connections with Duarte Fernandes, a Jewish merchant in Amsterdam, and Duarte Dias Henriques, the contratador of Angola in the period :607-14. ${ }^{43}$ Moreover, other Portuguese Jewish merchants in the period operating in the commercial circuits linking the Republic to Senegambia, Guinea Bissau and Cape Verde as well as other regions of the western coast of Africa, were also included in the list, namely Diogo Vaz (de Sousa) and Gaspar Nunes. ${ }^{44}$

After the establishment of the WIC (1621), the private merchants were forced to remove their economic agents from these areas within a period of two vears (by 1623). The WIC commercial agents replaced them. The establishment of a commercial monopoly with the WIC required a formal commercial and bureaucratic framework to organize and control trade. For those reasons, the western coast of Africa was divided into different commercial regions, namely: Gambia, Cape Verde, Arguin, Sierra Leone, Grain Coast, and the Gold Coast. The trading activities in each area were granted to specific chambers of the company. ${ }^{45}$ The Chamber of Groningen was responsible for the trade in the Gambia, while the commerce in the Cape Verde region, comprising the island of Gorée and several trading posts in the Petite Côte of Senegal, was under ine control of the Chamber of Amsterdam. The Chamber of Zealand was in charge of the trade in Arguin and the surrounding area of Cape Blanco, whils rade in Sierra Leone was organized by the Chamber of the Maas (i.e. Rotterdam),

Maria Manuel Ferraz, 'Rotas Comerciais, Agentes Económicos, Meios de Pagamento', in María Emilia Madeira Santos (ed.), História Geral de Cabo Verde (Lisbon and Praia (Cabo Verde): Centro de Eitudos de História e Cartografia Antiga, Instituto Nacional da Cultura de Cabo Verde, 1995 [vol. 2]) 44 GAA Not Arch 624/155v: 3 November 1617; Not Arch 611A/421: 20 June 1618; Nos [vol. 2]), 44 6: 8 December 1601 .

For Diogo Vaz (de Sousa): GAA Not Arch 62/206: 22 November 1610; Not Arch 160/28-29v - October 1619. For Gaspar Nunes: GAA Not Arch 117/22-23: 19 September 1609; Not Arch 201v: 1 November 1610; Not Arch 62/206: 22 November 1610; Not Arch 62/589: 31 January

12 ; Not Arch 375/516-516v: 20 September 1612.
See note 30. 
and the commerce in the Grain Coast by the Chamber of the Northern Quarter (see Figure 5.2). ${ }^{46}$

The most profitable commercial areas of the western coast of Africathe Gold and Slave Coasts, and the Loango Coast-were under the direct administration of the Board of Directors of the WIC, also known as Gentlemen Nineteen. ${ }^{47}$ Later, the regions of Angola and São Tomé also came under the direct rule of the Board (see Figure 5.3).

These areas were put under the direct administration of the Gentlemen Nineteen not only because they were the wealthiest, but also because they were the places in the western coast of Africa where the company and the States General had political and military interests to defend against the Portuguese. On the other hand, it is likely that the division of the western coast of Africa into different commercial areas was the best option found by the company in order to satisfy the interests of the private businessmen investing in these regions before the establishment of the WIC.

In the areas under the direct commercial administration of the chambers, these were responsible for the commercial personnel and the transport of goods, provisions, and ammunition. In the areas controlled by the Gentlemen Nineteen, the transport of employees, goods, victuals, and weaponry was provided by all the chambers proportionally to the capital invested in the company. ${ }^{48}$ In return, the chambers would have part of the profits obtained by the WIC in these areas.

${ }^{46} \mathrm{G}$ [emeente] A[rchie[] R[otterdam], Handel no. 83. A van Dantzig (ed.), The Dutch and the Guinea Coast, 1674-1742: A Collection of Documents from the General State Archive at the Hague (Accra: GAAS, 1978), doc. 1, 10-12.

${ }^{47}$ The direction of the WIC was given to an assembly — the Board of Directors-formed by nineteen directors-Gentlemen Nineteen - from the different chambers. Once again, the number of directors per chamber depended on the capital and the political and economic powers of the provinces and cities. Amsterdam and Zealand each had four directors on the Board, while the other three chambers had two each. Also, a member of the States General had a chair in this assembly. The Board was chaired by the chamber of either Amsterdam or Zealand. Amsterdam held the presidency during six consecutive years and Zealand for two. H. den Heijer, 'Directores, Stadhouderes e Conselhos de Administração,' 17-43; idem, Goud, Ivoor en Slaven, chapters 1, 2, and 3,; idem, De Geschiedenis van de WIC, chapters 1 and 2; Pieter Emmer, 'The West India Company, 1621-1791: Dutch or Atlantic,' 71-95.

${ }^{+8}$ For instance, in a report of the commission formed by the Gentlemen Nineteen to study the separation of the government of Angola from Brazil, dated 6 February 1642, the members of the commission explain clearly how the chambers should supply the establishment. Each chamber should send a vesse of 120 to 140 lasts ( 1 last $=2$ tonnes) every six weeks. Each ship should be equipped with 30 to 36 men, 16 to 18 pieces of light and heavy artillery, victuals for an entire year, and a cargo of merchandise worth up to 50,000 florins/guilders. The merchandise to be sent was listed in an enrolment provided to the chambers by the Board of Directors. N[ational] A[rchief], State Generaal no. 5773: 6 February 1642. Rapport de la comission formé par les XIX pour étudier de pro et le contre de la separation de Loanda avec le Brésil. This document is published in Louis Jadin (ed.), L'Ancien Congo et l'Angola
The commercial staff of the WIC followed a hierarchical order similar ar che one described earlier for the commercial agents serving the private - mpanies. In the Cape Verde region, the Chamber of Amsterdam kept one chief merchant, two to three sub-factors, and three to four assistants. For instance, in 1669. Jan van Dilsen and Carel le Coote were assistants at the Petite Côte of Eenegal. ${ }^{49}$ Therefore, it is likely that the chambers used the informal structures put in place by the private companies in the early years, since they had proved wo be well organized and worked efficiently for the success of trade.

Besides the company employees responsible for the organization of trade the WIC also appointed officials to supervise the commercial monopoly. These officials, called fiscals, were placed in the most profitable areas-the Gold Coast, Angola, and São Tomé- as well as on board the vessels conducting rade in the coastal areas. The fiscals were judicial officials who worked under the command and in straight collaboration with the director or director-general They had the power to inspect the cargoes on arrival at and departure from the iIC posts and settlements. They also had the right to make inventories and :ax the cargoes of any smuggler ship caught by the WIC cruisers patrolling the coast. These officials also had permission to confiscate smuggled goods and to arrest, try, and punish smuggling crews. In order to fulfil all their duties, the iscals were always supported by sub fiscals.

Between 1624 and 1642, the WIC had only one fiscal in Elmina, with urisdiction over all ships anchored at this port, as well as at the other company iorts, entrepôts, and lodges on the Gold and Slave Coasts. The establishment of WIC governments in Angola and São Tomé (1641) increased the number of fiscals in the western coast of Africa to three. The geographical areas under their jurisdiction became defined with the division of the western coast of Africa into three regions. After the loss of Angola and São Tomé (1648), the fiscal of Elmina remained as the single company fiscal for the whole coast until 1674. As for the regions of Senegambia, Guinea Bissau and Cape Verde we could not find references in the primary sources to any fiscals or sub fiscals operating in the region. These functions were most certainly assumed by the highest officer of the company in the region.

1639-1655, d'Après les Archives Romaines, Portugaises, Néerlandaises et Espagnoles (Bruxelles and Rome: Institut Historique Belge de Rome, 1975 [vol. 1]), doc. 76, 200-2.

GAR Handel no. 83. Also in A. van Dantzig (ed.), The Dutch and the Guinea Coast, doc. 1, 10-12. GAA Not Arch 2791/549: 11 October 1669; Not Arch 2791/709: 24 October 1669. 


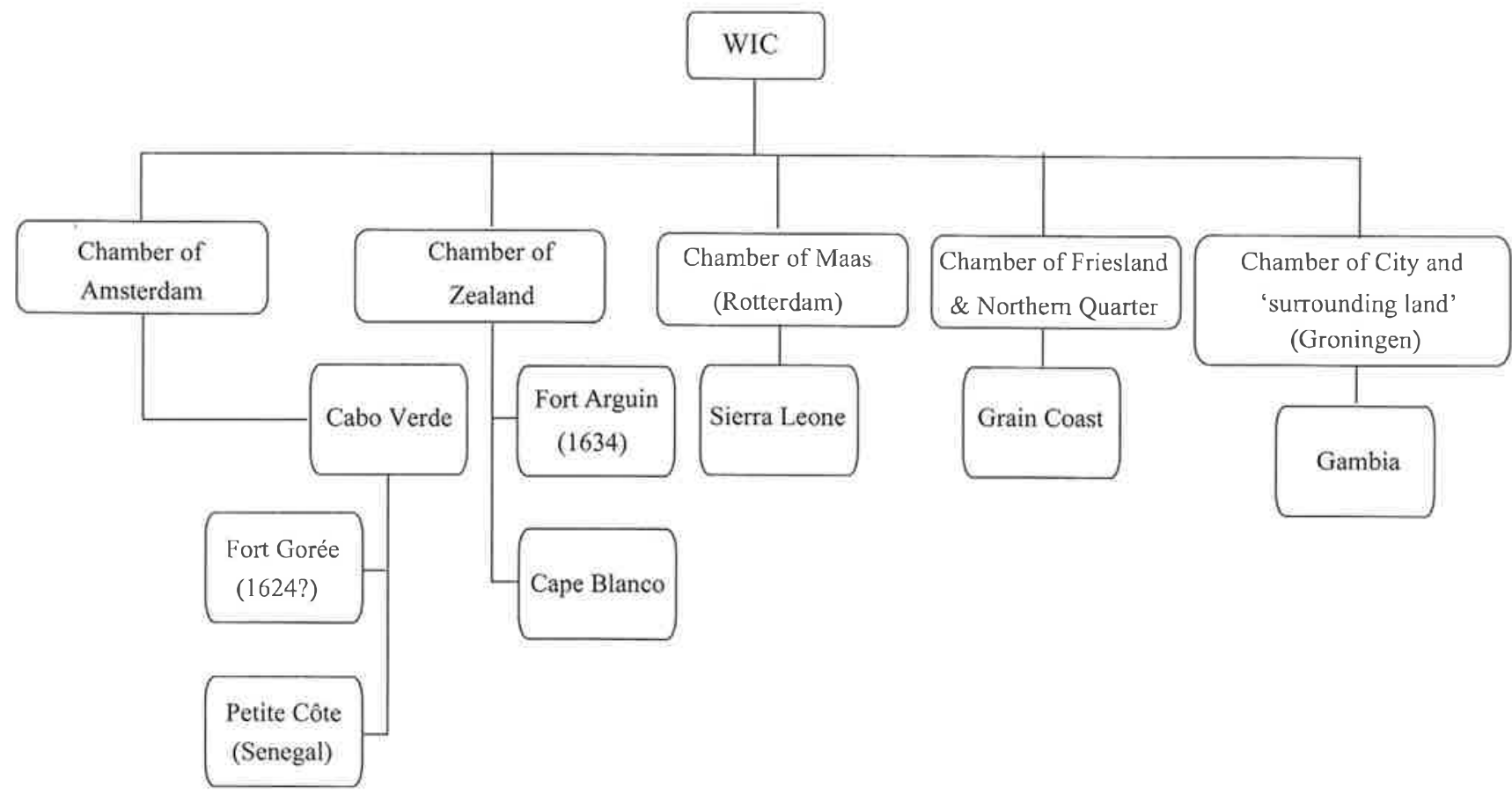

Figure 5.2 Jurisdiction of the chambers of the WIC over the different areas of the western coast of Africa

Sources: G[emeente] A[rchief] R[otterdam] Handel no. 83; A. van Dantzig (ed.), The Dutch and the Guinea Coast, 1674-1742: A Collection of Documents from the General State Archive at the Hague. (Accra: GAAS, 1978), doc 1, 10-12.

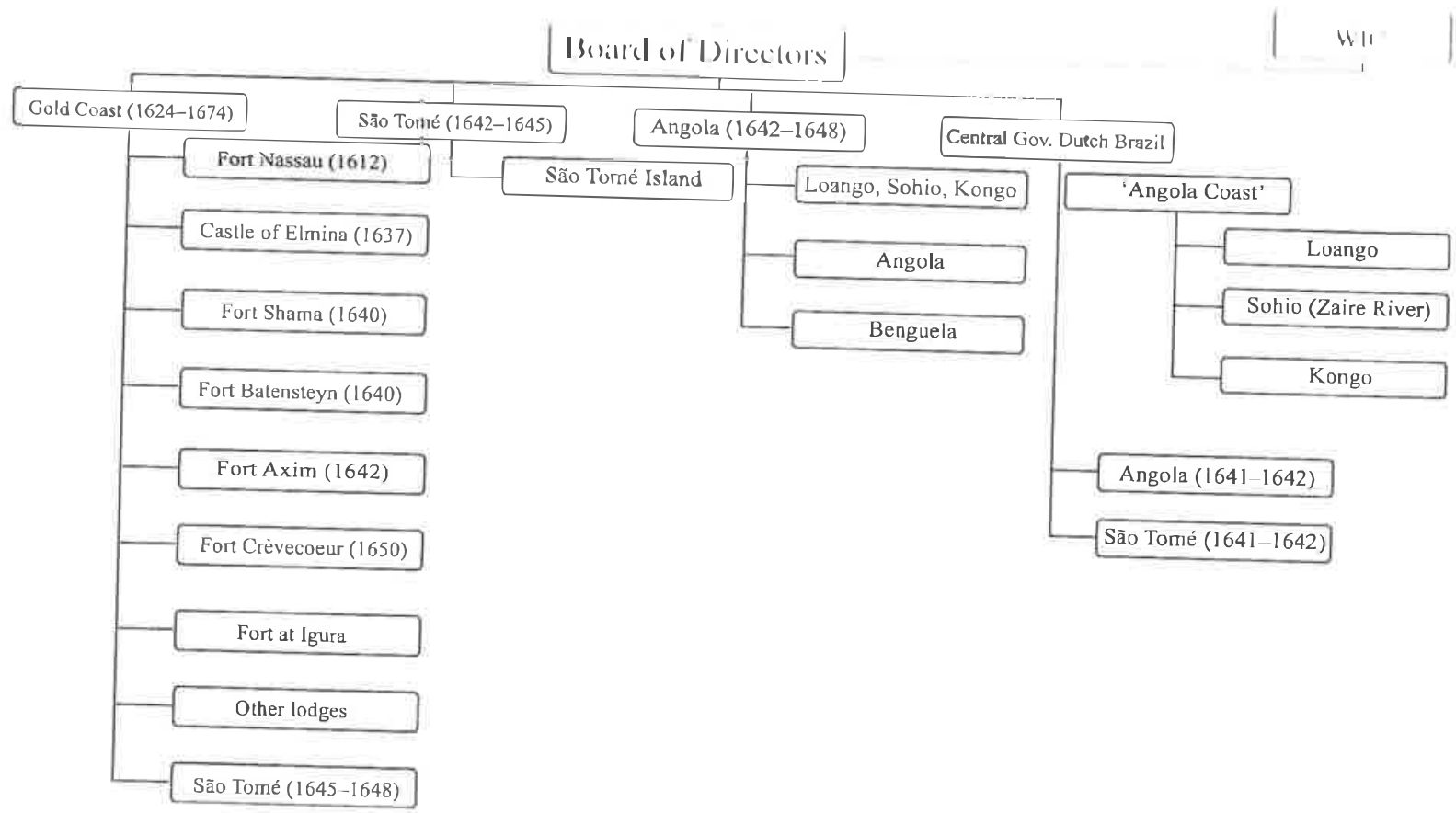

Figure 5.3 Jurisdiction of the Board of Directors and the Central Government of the Dutch West Indies over the different areas of the western coast of Africa (1624-74). Sources: NA Oude West Indische Compagnie (OWIC). GAR Handel no. 83; A. van Dantzig (ed.), The Dutch and the Guinea Coast, 1674-1742: A Colleclion of
Documents from the General State Archive at the Hague (Accra: GAAS, 1978), doc 1, 10-12; to the Assembly of Ten: 23 November 1679. Noles: Fort Nassau: Mori; Fort Crèvecoetr: A

Anomaboe (1638-39), Ardra, city of Benin, Cape Coast (1638-48), Loutry; Fort Amsterdam: Kormantin; Fort at Igura: Dwira. Other lodges comprised: Comany, 
Due to financial problems and limited shipping capacity, the WIC opened up its monopoly to private traders from the Republic. In 1638 the company allowed the participation of private businessmen in the Brazilian and Caribbean trades, and in 1648 granted them access to North America. This relaxing of its monopoly did not change the functions of company employees in charge of the trade organization, since they continued to conduct commerce with the African middlemen. The opening of some branches of the company monopoly to private merchants from the Dutch Republic, however, changed the functions of the fiscal and the auditor. Private traders were to pay commercial fees of 2.5 per cent over the value of the imports and exports-handelsrecognitien. ${ }^{50}$ The fiscal and the auditor were in charge of the collection of this fee. ${ }^{51}$ In the Senegambia region this fee was probably paid to the highest WIC official based at Gorée. This practice fuelled multiple conflicts between the WIC and private merchants. A good example of these clashes can be found in the 1660 s. Isaac Hoechepied Senior and Gillis Hoombeeck, merchants in Amsterdam, had an established trading network with the island of Goeree (Gorée). In order to keep a register of the goods traded there they hired Lammert Claesz as their junior clerk. He was supposed to work under the authority of Pieter van Asperen, the highest representative of the WIC in the region in 1666. Lammert Claesz served these merchants in this post from 28 March 1666 until September 1667. During his stay, he traded the commodities of these private businessmen at the fort. However, the coexistence of this agent and the WIC high officers seems to have been quite difficult. Lammert Claesz, Isaac Hoechepied Senior, and Gillis van Hoombeeck were accused of smuggling goods at the fort. ${ }^{52}$

As a consequence of the opening of the WIC monopoly over Brazil and New Netherland, in 1638 and 1648, respectively, an increasing number of ships freighted by private investors were to be found operating the intercontinental

${ }^{50}$ In the Dutch plantations colonies in Brazil, the Wild Coast, and the Caribbean Islands the fiscal also collected land taxes (akkergeld), as well as a head tax per colonist and per slave (hoofdgeld).

${ }_{51}$ Between the 1590s and 1612, the traders of the Dutch Republic operating in the westem coast of (a) foreign trade - the so-called Convooien en Licenten. These were collected by the admiralties of each province on behalf of the States General. The convooien were a tax imposed by the States General upon the circulation of goods, on the sale of salt, stamp duties, and several temporary taxes on beer and soap. The revenues from these taxes were to be spent on war fleets to protect the intemational trade and to support expenses of maritime conflicts. The main purpose of this tax imposition was in fact what gave it the name - convooien or convoys. The licenten-licences-,on the other hand, were duties imposed on trade with the enemy, i.e., Spain and Portugal.

52 GAA Not Arch 2296 1/63-65: 16 February 1668. Not Arch 2297/13-14: 6 March 1669. Not Arch

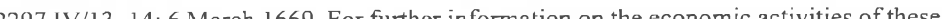
2297 IV/13-14:6 March 1669. For furt GAA Not Arch 2226/994-997: 28 April 1668; Not Arch 2229/855: 29 March 1669. circuits to and from the western coast of Africa. Therefore, supercargoes continued to be put on board vessels to conduct trade at the various ports of call. These supercargoes were not only in charge of selling the products sent from the Republic, and of purchasing new goods and putting them up for sale elsewhere, but they also had the autonomy to buy ships and engage in coastal trade in the various areas they were supposed to visit on behalf of their European employers. ${ }^{53}$

All the economic agents under analysis so far made the connection between the African ports and the international trading circuits linking these ports with the Americas and Europe. Behind these commercial agents was another layer of economic actors: those establishing a connection between the African coastal areas and the supply markets of African goods located deeper in the continent. Free Africans, Euro-Africans, and more rarely Europeans, the latter usually named tangomaos by the Portuguese authorities, were the connections between hese two worlds. These tangomaos lived not only in the ports, but also in the interior under the authority of the local African rulers, and, in some cases, they even had family ties with these authorities, ${ }^{54}$

Given the circumstances of their settlement and the shortage of primary sources, it is extremely difficult to identify who these men were. ${ }^{55}$ Nevertheless, in most cases they were traders and their main concern was to do business and make as much profit as possible in order to guarantee their own survival. Therefore they would trade with all European merchants settled on the coastal areas, be they Portuguese, Dutch, French, or English.

The private traders from the Republic did business with Portuguese and Euro-Africans in several points along the coast of Senegambia, namely at the ports of Rufisque, Portudal, and Joal on the Petite Côte of Senegal. ${ }^{56}$ These

G4A Not Arch 2757/133: 8 April 1661; Not Arch 2757A/153: 9 April 1661; Not Arch 2757A/149: Fril 1661; Not Arch 2757A/165: 9 April 1661; Not Arch 3586/235: 21 March 1670. For other examples: A Not Arch 1555B/1453: 8 October 1641; Not Arch 1611/52-53:23 Jly 1639; Nor Ar ches: December 1639

todré Alvares de Almada, Tratado Breve dos Rios de Guiné do Cabo Verde (Lisboa: Editorial L. I. Y.. 1964), 24-25; Isabel Castro Henriques, Os Pilares da Diferença: Relaçőes Portugal-Africa. nuios XV-XX (Lisbon: Calendoscópio, 2004), 352-3; Philip J. Havik. "Missionários e Moradores - Costa da Guiné: Os Padres da Companhia de Jesus e os Tangomãos no Principio do Século XVII iscia $56-57$ (2000): 225, 228, 230-2, 249 .

Among the merchants and citizens of Ribeira Grande (Santiago, Cape Verde) between 1560 and 48 , we could only identify two men who had lived for many years in the Guine Biss 1560 and Sente Ribeiro and Luis Lopes Rabelo. The latter was engaed on the coastal ands and the Nuno and Gambia rivers, together with two other merche Serra Grande: Francisco Ricalde or Francisco Recalde and Do other merchants, skippers, and citizens of 5 Cidade da Ribeira Grande de 1560 a 1648 ', in Mara Eiogo Ximenes Vargas: Iva Cabral, 'Vizinhos * Cabo Verde, 515-47.

D. La Fleur (ed.), Pieter van den Broecke's Journal 28, 87-91 
commercial transactions continued under the rule of the WIC in this region. In fact, in none of the territories taken over by the WIC did the company employees dare to penetrate much into the interior.

Taking these aspects into account makes it easier to understand and explain how these commercial agents served the interests of the WIC and the private merchants of the Republic simultaneously, while still pursuing their own ambitions. It also becomes easier to clarify how these economic agents trading within the commercial areas under Portuguese rule (at least nominally) could and did have commercial partnerships with merchants from an "enemy state' of the Portuguese and Spanish kingdoms—-such as the Dutch Republic. Finally, it becomes possible to explain how the Portuguese or people of mixed descent could supply African products to merchants from an 'enemy state', especially in the coastal areas

\section{Conclusion}

In brief, during the period under review, the Dutch entrepreneurs were not just insurers of ships and cargoes transported by the 'Dutch', Sephardic, and Portuguese merchants in the Atlantic world. Most of these entrepreneurs retained an indirect connection with the trade with the western coast of Africa by insuring ships and commodities for other traders operating the commercial circuits linking Europe to Africa and the Americas.

The case studies presented here also show that the 'Dutch' and the Portuguese Sephardic merchants of the Republic operated in areas of the western coast of Africa that were situated on the margins of the Portuguese presence in Africa, such as the Petite Côte of Senegal and the less-populated islands of Cape Verde. Whereas for the 'Dutch' this was a strategy to avoid naval and military conflicts with the representatives of the Portuguese Crown, which always increased costs and reduced profits, for the Sephardim this was also a strategy to avoid the payment of taxes to the fiscal officers of the Portuguese Crown in Ribeira Grande, São Tomé, and Luanda. In this way, they were able to operate their business without the control of the commercial agents of the Portuguese Crown, who supervised the transactions and made sure that the Crown did not lose money.

To complement their business in the western coast of Africa, Dutch private merchants also engaged in the Brazilian sugar and dyewood trade. These facts may help us to understand the reasons why the private merchants of Amsterdam were so reluctant to invest in the WIC and to support the attacks against the Portuguese Atlantic territories. For them the trade with the western coast of
Africa and Brazil were profitable enough without a commercial monopoly, ertitorial possessions, and a formal military apparatus. In fact during the WIC monopoly over trade with the western coast of Africa, the two groups used various strategies to overcome the commercial restrictions imposed on the Atlantic trade.

To operate their business, both the Dutch and the Sephardic merchants made use of similar agents on the western coast of Africa and recruited them in the same ways. Interestingly, the agents hired to be the supercargoes and actors of the Portuguese Jews had connections with Portuguese merchants conducting trade in the Portuguese settlements of Senegambia and Guinea Bissau on their behalf or on behalf of the contratadores of the royal monopolies.

Hence, this complex scheme of interconnections between the various eco7omic actors demonstrates clearly that the commercial interests of the businessmen living in Europe and in the various Atlantic colonial areas, whether under Portuguese or Dutch rule, transcended the political and geographical borders of the European Atlantic empires and the monopolistic ambitions of these early modern European states and their state-sponsored commercial companies. 